\title{
Leaving it all behind
}

\author{
S Hancocks, OBE*
}

\author{
There comes a time in all of our lives when we leave where we're working \\ and head, for a variety of reasons, for pastures new. In turn, a whole set of \\ rituals ensue.
}

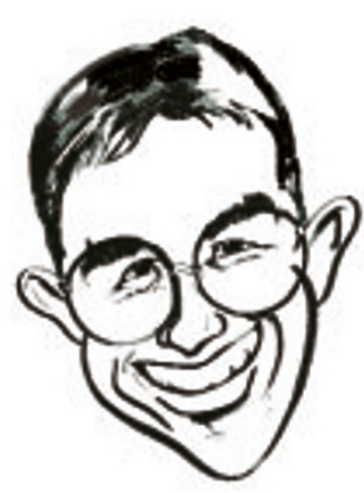

To begin with there is the tumult of emotion that greets you as the various members of the team get to hear the news. The reactions are usually predictable. The people who hate you make the most fuss. 'Oh, I'm so sorry to hear you're going. Where are you off to?'

A hardly subtle way of trying to discover if, in their opinion, it is far enough so they're never even likely to bump into you in the supermarket again, let alone in the dark room. Conversely, the people you are going to miss most and who you hope are going to miss you too, do the sort of slightly misty-eyed, mouth-scrunched-up look which says, 'well we're very happy for you but frankly we might not be here much longer ourselves now.'

After the initial burst of sentiment it goes eerily quiet. That's when the doubts can set in. If your team members aren't mentioning it on a regular basis does this mean that they really are pleased that you're off, or does it just mean that they're so devastated that they can't bear to bring the subject up again? You brood. And as you brood, they are planning. Planning two main activities, the card and collection and the 'leaving do.'

The card and collection are doing the rounds apparently without your knowledge. However, from time to time you catch sight of a member of staff furtively passing on to another colleague a large brown envelope, chinking with what is seemingly a cargo of loose coins sloshing around in the bottom, and looking very guilty that they have been caught doing so. Human nature makes you intrigued by how much the collection will raise. Modesty forbids you ever adding it up, even after you've received whatever it is.

It would be very unusual to find a 'sorry you are leaving', card specifically for dental practice. More often they have either office scenes or some form of cartoon characters.

In the former, workers are engaged in a variety of tasks ranging from dismantling the desk and effects of the person who is leaving, hauling them off to their own little territories, or already invading the leaver's desk, checking the drawers, swivelling in the seat and replacing the pictures on the wall with those of their own family, holiday snaps or favourite car. The cartoon characters tend to be a little less harsh. Fluffy bunnies with floppy ears and crestfallen looks or sad mice with gingham pocket handkerchiefs populate a landscape with the last traces of the leaver heading away over a hill, or into a glorious sunset emblazoned with rather predicatable sentiments like 'we'll miss you' or 'keep in touch' or the supremely bland 'good luck

Thank you all so much for this/these lovely gifts. . . but frankly I am so glad to be leaving here I will be dumping it/them in the nearest skip. . .

in the future'.

The 'leaving do' is quite another matter. This may have been organised with you or it may be, oh dear, a surprise! Surprises are usually worst but then again how much of a surprise can it be? A dental technician strip-o-gram? Hmm. Generally it is likely to involve some form of eating and drinking and taking time out of the usual flow of events after work. Most people are pleased to be there, some delighted and some irritated that it's stopping them going off to whatever it is they'd rather be doing instead of sipping warm Chardonnay and listening to the boss saying 'nice' things and you responding to the love and affection being poured down upon you from all present. Which brings us to the leaving speech. This can be a tricky one. You're leaving and unless it's being forced upon you by pregnancy, retirement or ter- minal illness you have probably chosen to leave. This can make it awkward in terms of what to say and how. 'Thank you all so much for this/these lovely gifts (how big was that collection? - the mean blighters!) but frankly I am so glad to be leaving here I will be dumping it/them in the nearest skip so that I never have to be reminded of you again as long as I live'. This may be honest but is probably not best guaranteed to win you long term friends should you ever want to even talk to them again when chance meeting at conferences and exhibitions. Although if it's really that bad maybe you don't care. Reason and politeness usually transpire. A liberal peppering of thoughts of the ilk of 'It is not so much that I want to leave as what I really want to

go on to,' or 'I know that even though I must move on I will never find such a collection of good friends as well as colleagues ever again' or, slightly more desperately 'I will think of you all, every time I look at this beautiful ceramic figurine of a dentist with a bloody white-coat and an extracted tooth in a pair of pliers - who can top a sense of humour like that?'

Then, when the last, crushed sausage roll has been scratched up from the waiting room carpet and the final goodbyes said, you walk away from the practice and glance back wistfully. Maybe they weren't such a bad crowd after all and, beside, book tokens and ball-point pens in smart plastic cases always come in useful don't they?

* Stephen Hancocks is Commissioning Editor of the BDJ 